\title{
An Assessment of Daily Plain Water, Fluid Intake Levels and Its Association with Total Energy Intake among Medical Students in Benghazi University in Libya
}

Zahzahan A. Alsaeti ${ }^{*}$, Hossniea Khalifa, Hamida Abdullah, Fatima Salam

University of Benghazi, Faculty of Public Health, Department of Nutrition, Benghazi, Libya

Article History

Received: 26.02.2021

Accepted: 07.04.2021

Published: 22.04 .2021

Journal homepage: https://www.easpublisher.com

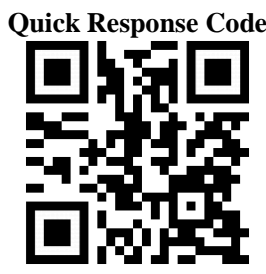

Abstract: Background: Water is the main component of the human body. The effect of an adequate fluid consumption is well-known and its relevance for the maintenance and promotion of health cannot be denied. Water is an essential nutrient for humans with several vital roles including: maintaining body functions, temperature and preventing dehydration. The human body consists of about $60 \%$ of water. The water in the body has numerous physiological roles: it is essential for the breathing (oxygen transport to the cells) and metabolism, digestion (absorption of nutrients). Nevertheless, many students ignore drinking water because of the modern lifestyle and the existence of alternatives to water. The previous studies notes that drinking water is connected with healthy dietary practices including reduced sugar-sweetened beverages consumption, but few studies considered the impact of drinking water on the total energy (calories) intake. Aim of study: This study was designed for evaluate of both plain water (pure water) and total water (water from pure water, beverages, and foods), and the intake is tested for its relationship with the daily energy intake, body mass index (BMI), and physical activity of students. Methods: This study was designed a cross-sectional descriptive study, a total number of 455 (231 females and 224 males) of medical college students were collected randomly, aged from 19-30 years, and collected from five medical faculties for all study years in the campus, ,food, fluid, and plain water intake of subjects was assessed, by 24-hour recall method. Dietary intake of subjects was analyzed manually by nutritionists. In this study, an assessment of the intake of both plain water (pure water) and total water (water from pure water, beverages, and foods) is performed, (drinking fluid values merged with data on the water content of foods and the rate of metabolic water were figured out. The mean of total and plain water intake made and analyzed (spss version20). Statistics testing: A significance testing such as a t-test, ANOVA and chi-square test we used. The intake both plain and total water intake was compared with its recommended levels, daily calories consumed, body mass index BMI, and physical activity of students. Results: Results indicated that in these age groups, plain water intake was $1627 \pm 1100 \mathrm{~mL} /$ day and total water intake was $2600 \pm 1282 \mathrm{~mL} /$ day for all participants. The plain water intake for male was $2190 \pm 1363$, and the plain water intake for female was $1384 \pm 992$. Total water intake for male was $3300 \pm$ 1627 , and $2360 \pm 1078$ for female. Furthermore, the results indicated that the plain water composes $43 \%$ of the daily total water intake for the whole study sample. In reference to Adequate Intakes (AIs), total water intake was closer to the recommended levels compared to plain water intake. Males showed better compliance with the recommended levels of AIs than females, Females who got less than the recommended daily intake of total water was $85.7 \%$ of the total female population compared to $68 \%$ for the general male's population. About a $22.8 \%$ males were above the recommended level of total water intake, compared to only $14 \%$ for females. The results also showed that male students more consumption of tea and coffee than female. While the consumption of male and female for milk and other beverages nearly the same. Total Water intake were strongly and positively correlated with plain water intake $(r=0.92, p<0.001)$. The statistical analysis showed no significant relationship between BMI and water 
intake in male and female were $(\mathrm{P}=0.845)(\mathrm{P}=0$.447) respectively. In addition there is no significant relationship between physical activity and water intake in male and female were $(\mathrm{P}=0.136)(\mathrm{P}=0.670)$ respectively. The study revealed the daily energy intake (Kcal) was positively correlated with total and plain water consumed $(\mathrm{r}=0.93, \mathrm{p}<0.001)$, direct intermediate correlation) with total water intake $(\mathrm{mL})$ with $\mathrm{p}$ value $\mathrm{p}=0.000$. Conclusion: We excluded that, most medical students were sedentary lifestyle. Plain Water intake was less than the Adequate Intakes (AIs), and they were depended on other fluids rather than plain water, therefore intensive nutritional educational intervention programs targeting medical students to improve their beverage choices. And they should be encouraged to drink the recommended amount of plain water in addition to maintain their weight by fallowing healthy diet and exercise. Finally, more studies need be conducted using various assessment tools with larger sample sizes.

Keyword: Water; Drinking Patterns; Fluid Intake; Beverage Consumption Pattern; University; Student.

Copyright (C) 2021 The Author(s): This is an open-access article distributed under the terms of the Creative Commons Attribution 4.0 International License (CC BY-NC 4.0) which permits unrestricted use, distribution, and reproduction in any medium for non-commercial use provided the original author and source are credited.

\section{INTRODUCTION}

Insufficient and inappropriate daily fluid intake in a long period may have adverse effect on human's health. Water is essential for life, is one of the most important substances on earth. All humans, plants and animals must have water to survive. If there was no water there would be no life on earth [1].This is important to us because we are mostly made of water, and knowing what water does for the human body, up to $60 \%$ of the human adult body is water, the brain and heart are composed of $73 \%$ water, and the lungs are about $83 \%$ water. The skin contains $64 \%$ water, muscles and kidneys are $79 \%$, and bones are $31 \%$. Each day humans must consume a certain amount of water to survive. Of course, this varies according to age and gender, and also by where someone lives. Generally, an adult male needs about 3 liters per day while an adult female needs about 2.2 liters per day. All of the water a person needs does not have to come from drinking liquids, as some of this water is contained in the food we eat [2]. Water is necessary for optimal cells, organs and tissues health to maintain other body functions [3]. Water has many biological functions as: a large heat capacity, which contributes to limiting changes in body temperature in a warm or cold environment. Water has a large capacity for vaporization of heat, which allows a loss of heat from the body even when ambient temperature is higher than body temperature [4]. Also, for several biological and physical processes such as: digestion, absorption, and excretion [5]. Water has many benefits, the most important of which is weight loss by enjoying good general health. Many studies have demonstrated the benefits of consuming a lot of high-quality water, such as the study published in the Journal of the American Dietetic Association (ADA) that found that, water can reduce the risks to the pyramid. The total of health problems such as breast cancer, colon cancer, obesity, urinary tract stones, etc. It has been proven that it has reduced certain risks from cancer by about (25-79\%) by drinking [5-10] cups of water every day [6]. Drinking large amounts of water is often recommended for weight control. water intake stimulates energy and fat metabolism, however, controversial with some studies reporting that drinking half a litre or more of water increases resting energy expenditure (REE) by $10-30 \%$ and decreases respiratory quotient (RQ), whereas others report no significant changes in REE or RQ [7].

Today, many students ignore drinking water because of the modern lifestyle and the existence of alternatives to water such as juices, drinks and the media to promote their products to attract the consumer [8], although everyone suffers from thirst from time to time. And it can delay the need to drink or stop drinking a quantity of water [9]. Studies in humans have shown that numerous factors affect fluid intake. Availability, flavor, flavor variety, beverage temperature, proximity of the beverage to the person, and even beverage container have all been shown to impact intake [4]. During increased physical activity and in conditions other than temperate, sweat loss contributes to body water loss [10]. The minimal amount of fluid loss that can occur is referred to as the obligatory water loss. However, a variety of factors can affect obligatory loss. For example, obligatory urine loss occurs because of the need to remove various solutes from the body [11]. The body loses water by breathing, sweating, and digestion. It's important to maintain drinking fluids and eating foods that contain water $[12,13]$. The amount of water need depends on a variety of factors, including the climate that live in, how physically active, and whether experiencing an illness or have any other health problems. Water is consumed from different sources, which include drinking water (tap and bottled water), beverages, moisture content of foods, and water produced by oxidative processes in the body [14]. Humans ingest water as plain drinking water, as beverages, and in food. Water in food can be inherent or added during preparation, and also produced by metabolism. All contribute to the total water intake 
[15]. Dehydration is loss water daily over period of time [16]. Because of excessive dehydration leads to poor cognitive and physical performance such as unwillingness to work, headache and dizziness [17]. People who drink small amounts of fluid are more likely to develop nephritis, Urinary tract and kidney stones [18]. Drinking liquids such as milk, light stimulants (such as tea and coffee) and soft drinks because they contain calories provide energy and not because of thirst [19]. The required water of body could be supplied with various beverages including water, milk, tea, fruit juices, coffee, and soft drinks. For example research conducted in 2015 by Guelinckx et al., about Intake of water and other three continents beverages of children and adolescents samples of 3611 children (4-9 years) and 8109 adolescents (10-17 years). The study showed that across the total samples of the countries, the highest daily intakes were observed for water (738 $\pm 567 \mathrm{~mL} /$ day), followed by milk ( $212 \pm$ $209 \mathrm{~mL} /$ day $)$, regular soft beverages RSB $(168 \pm 290$ $\mathrm{mL} /$ day $)$ and juices $(128 \pm 228 \mathrm{~mL} /$ day $)$ [20]. The proportion of water that comes from beverages and food varies according to the proportion of fruits and vegetables in the diet [21].

Athletes should drink enough fluid or should be well hydrated prior to exercise. The goal of preexercise fluid intake is critical for decreasing the risk of dehydration (loss of body water) and its negative health consequences (e.g., heart disease), and maintaining exercise performance [22]. Study in 2018 by Alanazi, assessment of daily Plain water (pure water) intake level and its association with total energy intake, the study presented both plain water and total water (water from pure water, beverages, and foods) relationship with the daily calories consumed among college students .The plain water intake of all participants was Less than the requirements. It was found that the daily energy intake (Kcal) was positively correlated with total water intake [23]. The type of fluid consumed by individuals should also have received attention [24, 25]. In fact, young People in this age group are vulnerable to develop unhealthy behaviors [26, 27], which will predispose them to chronic diseases later in life [28]. A longitudinal study tracking soft drink intake from early adolescence to later adulthood demonstrated that soft drink consumption from young adulthood remained stable [29]. This data indicates beverage consumption habits formed during young adulthood may have a strong impact on beverage choices in later life. Insufficient and inadequate daily fluid in a prolonged period may have a negative impact on human health [30]. The first effect it is dehydration. Several factors may increase the likelihood of chronic or mild dehydration, including a poor thirst mechanism, dissatisfaction with the taste of water, common consumption of the natural diuretics caffeine, participation in exercise, and environmental conditions. Young adulthood is a unique period whereby youth obtain independence from their parents. This age group is more susceptible for unhealthy drink choice [31, 32]. Therefore the choice type of beverages consumed by students should also have received attention [33]. The required water of body could be supplied with various beverages including water, milk, tea, fruit juices, coffee, and soft drinks. However, regarding their nutritional value and their effect on health, it is necessary to have a healthy drinking pattern during life cycle. In fact, this will predispose them to chronic diseases later in life [34]. "A longitudinal study tracking soft drink intake from early adolescence to later adulthood demonstrated that soft drink consumption from young adulthood remained stable" [35]. This data indicates beverage consumption adulthood may have a strong impact on beverage choices in later life. Due to the conflict between researchers about whether the medical students drinking an adequate amounts of water or no, this study is to explore the total and plain water intake, body weight and physical activity levels of medical college students of Benghazi University. Considering the importance of student's health as young members of society they will be able to direct the people for healthy lifestyle.

\section{Aim OF STUdY}

The present study to evaluate the amount of total and plain water intake, and source of fluids consumed by medical students. To determine whether these amounts and sources of fluid were enough and appropriate. Also to study the correlation between daily water intake, total energy intake, BMI, and, physical activity. In addition to distinguish between male and female medical students in their water consumption, and to determine the most popular drinks for medical students.

\section{Methodology}

Study design: The study applied a (crosssectional), (descriptive study design).

Study area: Medical students who were enrolled in Benghazi University in Libya.

Study population: Randomly selected from a sampling from all department of university (medicine, dental, pharmacy, public health and medical technique) aged between (19-30) years .There is sample size of 450 students (224 male and 231 female).

Data collection method: Data were collected using a structured dietary pattern questionnaire. Information on demographic characteristic, feeding habit, and dietary practices $24 \mathrm{~h}$ recall were obtained using self-administered questionnaires to respondents. We asked them how much water and beverage they consumed in cup within 24 hours, and we use a nutrient composition of food. And then we converted it to the volume in liters. It was coded with a unique number 
representing each respondent. The questionnaire was used to collect the following information:

Socio-demographic characteristics: This comprise information on age, gender, course of study, year of study and this provided background information of students recruited into the study.

\section{Anthropometric}

measurements: Anthropometric measurements of weight and height were taken with the respondents wearing light clothes and no shoes. The body mass index (BMI) was calculated (weight for height) for all sample students.

Weight measurement: To ensure reliable measurements of body weight using the mechanical bathroom scale, the scale was zeroed before the respondent stepped onto it. The respondents were asked to remove any 'heavy' items from their pockets (key's, wallets etc.) and remove any heavy items of clothing or apparel (big jackets, shoes, woolen jerseys etc.). They were asked to look straight ahead and stay still on the scales. The needle/digital screen was allowed to settle before the measurement was recorded. The body weight $(\mathrm{kg})$ was measured to the nearest $0.5 \mathrm{~kg}$.

Height measurement: Height measurement was taken using a "drop down" tape measure fixed at about $2 \mathrm{~m}$ on a wall. The respondents were asked to remove their shoes prior to taking the measurement. They were asked to stand with their back to the wall and look directly forward. The back of their feet, calves, bottom, upper back, and the back of their head should be in contact with the wall. They were positioned directly underneath the drop down measuring device. The measuring device was lowered until it rested gently on the top of the respondent's head and the measurement was recorded. Their height $(\mathrm{m})$ to the nearest $0.5 \mathrm{~cm}$ was recorded.

\section{Data Analysis}

Data presentation: Mean standard division; frequency distribution table and column charts were used to describe and compare variables. Statistics testing: A significance testing such as a t-test, ANOVA and chi-square test were used to examine the difference mean of variables; a p-value of less than 0.05 is statistically significant. Data analysis: was executed using the statistics package social science (SPSS) program version 20 .

\section{RESULT}

Demographics

A total of 455 participants of medical college students were divided to 224 samples male and 231 samples female aged from 19-30 years completed the study. According to the results the age was divided to 3 groups and weight was divided to 3 groups. The results showed the majority of students at age 23-26 year were students n 321 (70.5\%), 19-22 year were students n 96 $(21.1 \%)$, and $27-30$ year n $38(8.4 \%)$. The gender distribution nearly the same, were females $(51 \%)$, males sample was (49\%). About $68 \%$ of the sample population had normal BMI range, while $22.8 \%$ were overweight, $4.8 \%$ were obese, and only $3.7 \%$ were underweight. When participants were asked about their physical activity, most of them reported being sedentary lifestyle $61 \%$, followed by being moderately $30 \%$, and only $8.5 \%$ reported having an extreme activity (Table $1)$.

Table-1: General student's characteristics gender, age, body mass index, and physical activity level

\begin{tabular}{|l|c|c|}
\hline Variable & $\mathbf{N}=\mathbf{4 5 5}$ & Percentage (\%) \\
\hline Gender & 224 & $49 \%$ \\
\hline Male & 231 & $51 \%$ \\
\hline Female & 96 & $21.1 \%$ \\
\hline Ages ( years) & 321 & $70.5 \%$ \\
\hline $19-22$ & 38 & $8.4 \%$ \\
\hline $23-26$ & 17 & $3.736 \%$ \\
\hline $27-30$ & 311 & $68.35 \%$ \\
\hline BMI (Kg/m2) & 104 & $22.86 \%$ \\
\hline Underweight <18.5 & 22 & $4.8 \%$ \\
\hline Normal 18.5-24.9 & 279 & $61.3 \%$ \\
\hline Overweight 25-29.9 & 137 & $30.1 \%$ \\
\hline Obese >30 & 39 & $8.5 \%$ \\
\hline Physical activity & \\
\hline Sedentary &
\end{tabular}

Faculty and education years of students

This study included all years of medical students at the University of Benghazi, and the results were shown as following majors including medical students $(38 \%)$, public health $(34.5 \%)$, pharmacy (14\%), and medical technology $(7.3 \%)$, and dental (5.9 $\%)$. The majority of the students $(49 \%)$ were in their fourth year of education; whereas, the remaining represented first year $14.9 \%$, second $16 \%$ and third year was $19.8 \%$ (Table 2).

Table-2: Students samples, categorized by education study year and faculty

\begin{tabular}{|l|l|l|l|l|l|}
\hline Faculty & $(\mathbf{N})$ & $\mathbf{\%}$ & Year & $(\mathbf{N})$ & \% \\
\hline Medical & 174 & 38.24 & First & 68 & 14.9 \\
\hline Pharmacy & 64 & 14.1 & Second & 74 & 16.26 \\
\hline Dental & 27 & 5.9 & Third & 90 & 19.8 \\
\hline Public Health & 157 & 34.50 & Forth & 223 & 49.01 \\
\hline Medical technology & 33 & 7.3 & - & - & - \\
\hline Total & 455 & 100 & Total & 455 & 100 \\
\hline
\end{tabular}




\section{Assessment of Total and Plain Water Intake}

There is a gender difference in the recommended Institute of Medicine (IOM) Adequate Intakes (AIs) levels for assessing total water intake, of which it is 3 Liter for men and 2.2 Liter for women. The number of males who drank plain water as per the suggested recommendations $(8.9 \%)$, Females who got less than the recommended daily intake of total water were $85.7 \%$ of the total female population compared to $68 \%$ for the general male's population. About $22.8 \%$ of males were above the recommended level of total water intake, compared to only $14.3 \%$ for female. The analysis revealed that the plain water intake of all participants was $1627 \pm 1100 \mathrm{~mL}$ (Mean \pm SD), for females it was $1384 \pm 992 \mathrm{~mL}$ and for males $2190 \pm$
$1363 \mathrm{~mL}$. The total water intake for all participants was $2600 \pm 1282 \mathrm{~mL}$, for female's $2360 \pm 1078 \mathrm{~mL}$ and for male's $3300 \pm 1627 \mathrm{~mL}$. The number of males who drank plain water as per the suggested recommendations $(12 \%)$ compared with female plain water intake $(0 \%)$. Furthermore, IOM AIs for the plain water intake, which is $3000 \mathrm{~mL}$ for males and $2200 \mathrm{~mL}$ for females, found to have more below recommended intakes. Females who got less than the recommended daily intake of total water were $85.7 \%$ of the total female population compared to $68 \%$ for the general male's population. Plain water were strongly and positively correlated with total water intake $(\mathrm{r}=0.92$, $\mathrm{p}<0.001)$ (Table 3).

Table-3: Assessment Total and plain Water Intake by Gender

\begin{tabular}{|l|l|l|l|}
\hline \multirow{3}{*}{ Gender } & Intake Level & $\begin{array}{l}\text { Total Water } \\
\text { Percent \% }\end{array}$ & $\begin{array}{l}\text { Plain Water } \\
\text { Percent \% }\end{array}$ \\
\hline \multirow{3}{*}{ Female } & Below Recommendations & $85.7 \%$ & $88 \%$ \\
\cline { 2 - 4 } & Recommended Intake & $0 \%$ & $0 \%$ \\
\cline { 2 - 4 } & Above Recommendations & $14.3 \%$ & $12 \%$ \\
\hline \multirow{3}{*}{ Male } & Below Recommendations & $68.3 \%$ & $60 \%$ \\
\cline { 2 - 4 } & Recommended Intake & $8.9 \%$ & $12 \%$ \\
\cline { 2 - 4 } & Above Recommendations & $22.8 \%$ & $28 \%$ \\
\hline
\end{tabular}

\section{Association of Physical Activity with Total Water Intake of Male}

The statistical analysis showed no significant relationship between levels of Physical activity and water intake in male $(\mathrm{P}=0.136)$. The results showed that about $10.3 \%$ of students with extreme activity consumed less than $3 \mathrm{~L} /$ day and only $0.9 \%$ students with extremely active consumed more than $3 \mathrm{~L} /$ day. While in moderately active $20.5 \%$ of students consumed less than $3 \mathrm{~L} /$ day of water, $5.8 \%$ consumed more than $3 \mathrm{~L} /$ day of water, and about $3.1 \%$ of students consumed $3 \mathrm{~L} /$ day of water. Sedentary student was consumed less than $3 \mathrm{~L} /$ day of water $37.5 \%, 16.1 \%$ of students consumed more than $3 \mathrm{~L} /$ day of water and only $4.9 \%$ of students consumed $3 \mathrm{~L} /$ day of water. The results also showed that $68.3 \%$ students from the total were water consumed less than $3 \mathrm{~L} /$ day, $8.9 \%$ consumed $3 \mathrm{~L} /$ day and about $22.8 \%$ were consumed more than $3 \mathrm{~L} /$ day (Table 4).

Table-4: The association between Physical activity and total water intake in male

\begin{tabular}{|c|c|c|c|c|c|c|c|c|}
\hline \multirow[t]{3}{*}{ Physical activity } & \multicolumn{6}{|c|}{ Total water intake for male in liter } & \multirow{2}{*}{\multicolumn{2}{|c|}{ Total }} \\
\hline & \multicolumn{2}{|l|}{$<3$} & \multicolumn{2}{|c|}{$=\mathbf{3}$} & \multicolumn{2}{|l|}{$>3$} & & \\
\hline & $\mathbf{N}$ & $\%$ & $\mathbf{N}$ & $\%$ & $\mathbf{N}$ & $\%$ & $\mathbf{N}$ & $\%$ \\
\hline Extremely active & 23 & $10.3 \%$ & 2 & $0.9 \%$ & 2 & $0.9 \%$ & 27 & $12.1 \%$ \\
\hline Moderately active & 46 & $20.5 \%$ & 7 & $3.1 \%$ & 13 & $5.8 \%$ & 66 & $29.5 \%$ \\
\hline Sedentary & 84 & $37.5 \%$ & 11 & $4.9 \%$ & 36 & $16.1 \%$ & 131 & $58.5 \%$ \\
\hline Total & 153 & $68.3 \%$ & 20 & $8.9 \%$ & 51 & $22.8 \%$ & 224 & $100.0 \%$ \\
\hline
\end{tabular}

\section{Association of Physical Activity with Total Water Intake of Female}

The statistical analysis showed no significant relationship between Physical activity level and water intake in female $(\mathrm{P}=0.670)$. The results showed that about $4.3 \%$ of female students with extreme activity her consumption less than $2.2 \mathrm{~L} /$ day of water and only $0.9 \%$ students extremely active consumption more than $2.2 \mathrm{~L} /$ day of water. In moderate activity $27.3 \%$ of students consumption less than $2.2 \mathrm{~L} /$ day of water, and $3.5 \%$ consumption more than $2.2 \mathrm{~L} /$ day of water. In sedentary life was higher percentage about $54.1 \%$ of student's consumption less than $2.2 \mathrm{~L} /$ day of water, and only $10 \%$ of student's consumption more than $2.2 \mathrm{~L} /$ day of water .The results also showed that $85.7 \%$ students from the total were water consumption less than $2.2 \mathrm{~L} /$ day, and about $14.3 \%$ of females students were consumption more than $2.2 \mathrm{~L} /$ day (Table 5). 
Table-5: The association between Physical activity and total water intake in female

\begin{tabular}{|l|l|l|l|l|l|c|}
\hline \multirow{3}{*}{ Physical activity } & \multicolumn{6}{|c|}{ Total Water intake in female in liter } \\
\cline { 2 - 7 } & \multicolumn{3}{|c|}{$<\mathbf{2 .}$} & \multicolumn{2}{c|}{$>\mathbf{2 . 2}$ } & \multicolumn{1}{c|}{ Total } \\
\cline { 2 - 7 } & $\mathbf{N}$ & $\mathbf{\%}$ & $\mathbf{N}$ & $\mathbf{\%}$ & $\mathbf{N}$ & \% \\
\hline Extremely active & 10 & $4.3 \%$ & 2 & $0.9 \%$ & 12 & $5.2 \%$ \\
\hline Moderately active & 63 & $27.3 \%$ & 8 & $3.5 \%$ & 71 & $30.7 \%$ \\
\hline Sedentary & 125 & $54.1 \%$ & 23 & $10.0 \%$ & 148 & $64.1 \%$ \\
\hline Total & 198 & $85.7 \%$ & 33 & $14.3 \%$ & 231 & $100.0 \%$ \\
\hline \multicolumn{7}{|c|}{ P value 0.670} \\
\hline
\end{tabular}

\section{Association of BMI with Total Water intake of Male}

The association between BMI and total water intake in male, according to total consumption per day for male about $3 \mathrm{~L} /$ day. The statistical analysis showed no significant relationship between BMI and water intake in male $(\mathrm{P}=0.845)$. The results showed that students have BMI Underweight $<18.5$, were water consumption $<3$ L/day with percentage $0.9 \%$ and $>3$ L/day was $0.4 \%$. Student have BMI normal 18.5 - 24.9, water consumption <3 L/day were $43 \%$ of students, student have consumption $3 \mathrm{~L} /$ day were percentage $6.3 \%$, and about $16.5 \%$ were consumption $>3$ L/day. student have BMI Overweight 25 - 29.9, water consumption less than $3 \mathrm{~L}$ /day were $20.1 \%$ student have consumption $3 \mathrm{~L}$ /day were $2.2 \%$, and about $4.5 \%$ of students were consumption more than $3 \mathrm{~L} /$ day. student have BMI Obese 30 or more water consumption less than $3 \mathrm{~L} /$ day were $4.0 \%$ student have consumption $3 \mathrm{~L} /$ day was with percentage $0.4 \%$, and about $1.3 \%$ students were consumption more than 3 L/day. The results also showed that $68.3 \%$ students from the total were water consumption less than $3 \mathrm{~L} /$ day, $8.9 \%$ consumption $3 \mathrm{~L} /$ day and about $22.8 \%$ were consumption more than $3 \mathrm{~L} /$ day (Table 6).

Table-6: The association between BMI and water intake in male

\begin{tabular}{|c|c|c|c|c|c|c|c|c|}
\hline \multirow[t]{3}{*}{ BMI } & \multicolumn{6}{|c|}{ Total water intake for male in liter } & \multirow{2}{*}{\multicolumn{2}{|c|}{ Total }} \\
\hline & \multicolumn{2}{|l|}{$<3$} & \multicolumn{2}{|c|}{$=\mathbf{3}$} & \multicolumn{2}{|c|}{$>\mathbf{3}$} & & \\
\hline & $\mathbf{N}$ & $\%$ & $\mathbf{N}$ & $\%$ & $\mathbf{N}$ & $\%$ & $\mathbf{N}$ & $\%$ \\
\hline Underweight $<18.5$ & 2 & 0.9 & 0 & 0 & 1 & 0.4 & 3 & 1.3 \\
\hline Normal $18.5-24.9$ & 97 & 43.3 & 14 & 6.3 & 37 & 16.5 & 148 & 66.1 \\
\hline Overweight 25-29.9 & 45 & 20.1 & 5 & 2.2 & 10 & 4.5 & 60 & 26.8 \\
\hline Obese 30 or more & 9 & 4.0 & 1 & 0.4 & 3 & 1.3 & 13 & 5.8 \\
\hline Total & 153 & 68.3 & 20 & 8.9 & 51 & 22.8 & 224 & 100.0 \\
\hline
\end{tabular}

\section{Association of BMI with Total Water intake of Female}

The statistical analysis showed no significant relationship between BMI and water intake in female $(\mathrm{P}=0$.447). The association between BMI and water intake in female students according to total consumption per day for male about $2.2 \mathrm{~L} /$ day and divided in to four groups according to body mass index. The results showed that students have BMI Underweight $<18.5$, were water consumption $<2.2$ L/day with percentage $5.6 \%$ and students consumption $>2.2 \mathrm{~L} /$ day was with percentage $1.4 \%$. Student have
BMI Normal 18.5 - 24.9, water consumption <2.2 L/day were students with percentage $60.2 \%$, and about $10.4 \%$ were consumption $>2.2$ L/day. Students have BMI Overweight 25 - 29.9, water consumption $<2.2$ L/day were $16.9 \%$ students, and about $2.2 \%$ were consumption $>2.2$ L/day. Student have BMI Obese 30 or more, water consumption $<2.2 \mathrm{~L} /$ day were $3.0 \%$ and about $1.3 \%$ were consumption $>2.2 \mathrm{~L} / \mathrm{day}$. The results also showed that $85.7 \%$ students from the total were water consumption less than $2.2 \mathrm{~L} / \mathrm{day}$, and about $14.3 \%$ were consumption more than $2.2 \mathrm{~L} /$ day (Table 7).

Table-7: The association between BMI and water intake in female

\begin{tabular}{|l|l|l|l|l|l|l|}
\hline \multirow{2}{*}{ BMI } & \multicolumn{3}{|c|}{ Total water intake for female in liter } \\
\cline { 2 - 8 } & \multicolumn{2}{|c|}{$<\mathbf{2}$} & \multicolumn{2}{c|}{$>\mathbf{2 . 2}$} & \multicolumn{2}{c|}{ Total } \\
\cline { 2 - 8 } & $\mathbf{N}$ & $\mathbf{\%}$ & $\mathbf{N}$ & $\mathbf{\%}$ & $\mathbf{N}$ & $\mathbf{\%}$ \\
\hline Underweight $<18.5$ & 13 & 5.6 & 1 & 1.4 & 14 & 6.1 \\
\hline Normal 18.5 - 24.9 & 139 & 60.2 & 24 & 10.4 & 163 & 70.6 \\
\hline Overweight 25 - 29.9 & 39 & 16.9 & 5 & 2.2 & 44 & 19.0 \\
\hline Obese 30 or more & 7 & 3.0 & 3 & 1.3 & 10 & 4.3 \\
\hline Total & 198 & 85.7 & 33 & 14.3 & 231 & 100.0 \\
\hline P value 0.447 & \multicolumn{7}{|l|}{} \\
\hline
\end{tabular}




\section{Milk Consumption in Students}

The statistical analysis showed no significant relationship between milk consumption and gender $\mathrm{P}=0.602$. The association between milk intake in male and female students according to consumption per day, the results showed that student no milk consumption about $9.0 \%$ for male and $8.4 \%$ for female students. The results also showed female slightly more consumption for milk than male were $42.4 \%$ for female and $40.2 \%$ for male students (Table 8).

Table-8: Correlation between milk consumption and gender

\begin{tabular}{|l|l|l|l|l|l|l|}
\hline \multirow{3}{*}{ Milk consumption } & \multicolumn{9}{|c|}{ Gender } \\
\cline { 2 - 7 } & Male & \multicolumn{1}{|l|}{ female } & \multicolumn{2}{|c|}{ Total } \\
\cline { 2 - 7 } & $\mathbf{N}$ & $\mathbf{\%}$ & $\mathbf{N}$ & $\mathbf{\%}$ & $\mathbf{N}$ & $\%$ \\
\hline No & 41 & $9.0 \%$ & 38 & $8.4 \%$ & 79 & $17.4 \%$ \\
\hline $0.25-1$ liter & 183 & $40.2 \%$ & 193 & $42.4 \%$ & 376 & $82.6 \%$ \\
\hline Total & 224 & $49.2 \%$ & 231 & $50.8 \%$ & 455 & $100.0 \%$ \\
\hline P value 0.602 & \multicolumn{7}{|l|}{} \\
\hline
\end{tabular}

\section{Tea Consumption of Students}

The statistical analysis showed highly significant relationship between Tea consumption and gender $(\mathrm{P}=0.000)$. The association between tea intake in male and female students according to consumption per day, the results showed that about $13.0 \%$ of male and
$24.8 \%$ of female consumption for tea. the results also showed that about $36.3 \%$ of male students and $25.9 \%$ of female students were tea consumption from $0.25 \mathrm{ml}$ $1 \mathrm{~L}$, male students more consumption of tea than female students (Table 9).

Table-9: Correlation between Tea consumption and gender

\begin{tabular}{|l|l|l|l|l|l|l|}
\hline \multirow{3}{*}{ Tea consumption } & \multicolumn{9}{|c|}{ Gender } & \multicolumn{2}{|c|}{ Total } \\
\cline { 2 - 7 } & Male & \multicolumn{1}{|c|}{ female } & N & $\%$ \\
\cline { 2 - 7 } & $\mathrm{N}$ & $\%$ & $\mathrm{~N}$ & $\%$ & $\mathrm{~N}$ & 37.8 \\
\hline No & 59 & 13.0 & 113 & 24.8 & 172 & 37 \\
\hline $0.25-1$ Liter & 165 & 36.3 & 118 & 25.9 & 283 & 62.2 \\
\hline Total & 224 & 49.2 & 231 & 50.8 & 455 & 100.0 \\
\hline P Value 0.000 & \multicolumn{9}{|l}{} \\
\hline
\end{tabular}

\section{Coffee Consumption of Students}

The statistical analysis showed highly significant relationship between coffee consumption and gender $(\mathrm{P}=0.001)$. The association between coffee intake in male and female students according to consumption per day, the results showed that about $5.5 \%$ of male and $11.4 \%$ of female students were no consumption of coffee. The results also showed that about $42.6 \%$ of male students and $39.1 \%$ of female students consumption about $0.25 \mathrm{ml}-1 \mathrm{~L}$ of coffee, and consumption more than $1 \mathrm{~L}$ about $1.1 \%$ and $0.2 \%$ for male and female respectively, male students more consumption of coffee than female students (Table 10).

Table-10: Correlation between Coffee consumption and gender

\begin{tabular}{|c|c|c|c|c|c|c|}
\hline \multirow[t]{3}{*}{ Coffee consumption } & \multicolumn{6}{|c|}{ Gender } \\
\hline & \multicolumn{2}{|c|}{ Male } & \multicolumn{2}{|c|}{ female } & \multicolumn{2}{|c|}{ Total } \\
\hline & $\mathbf{N}$ & $\%$ & $\mathbf{N}$ & $\%$ & $\mathbf{N}$ & $\%$ \\
\hline No & 25 & $5.5 \%$ & 52 & $11.4 \%$ & 77 & $16.9 \%$ \\
\hline $0.25-1$ Liter & 194 & $42.6 \%$ & 178 & $39.1 \%$ & 372 & $81.8 \%$ \\
\hline$>1 \quad$ Liter & 5 & $1.1 \%$ & 1 & $0.2 \%$ & 6 & $1.3 \%$ \\
\hline Total & 224 & $49.2 \%$ & 231 & $50.8 \%$ & 455 & $100.0 \%$ \\
\hline
\end{tabular}




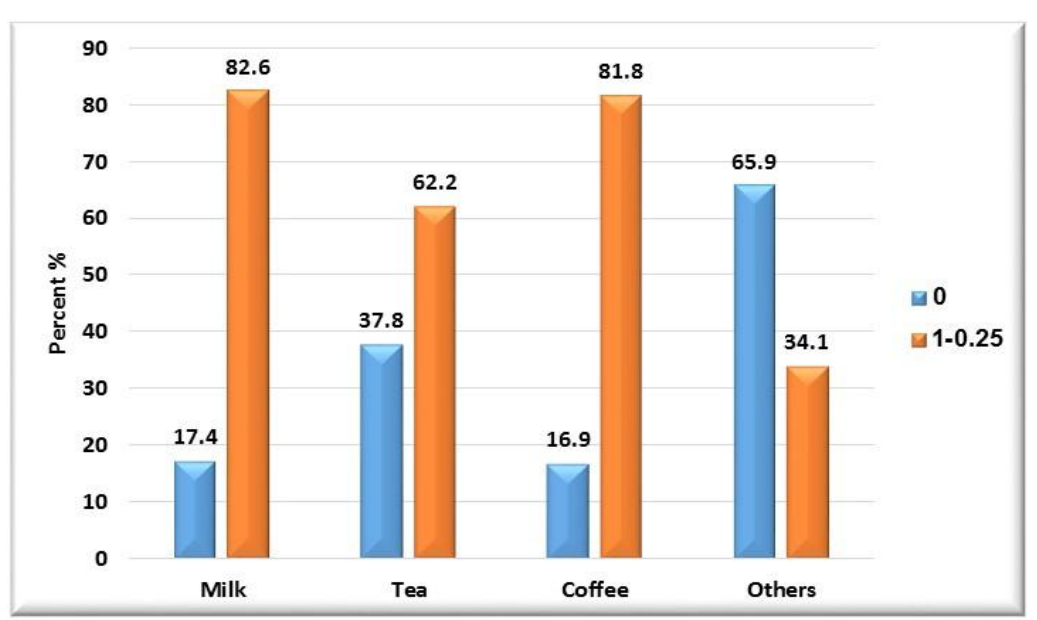

Fig-1: General consumption of milk, tea, coffee, and other beverages in students (male and female)

Figure showed that $82.6 \%$ of students consumption about 0.25 -1L of milk, 81.8 of students consumption about $0.25-1 \mathrm{~L}$ of coffee, $62.2 \%$ of students consumption about $0.25-1 \mathrm{~L}$ of tea and, $34.1 \%$ of students consumption about $0.25-1 \mathrm{~L}$ of other beverage.

\section{Water and Energy Intake of Students}

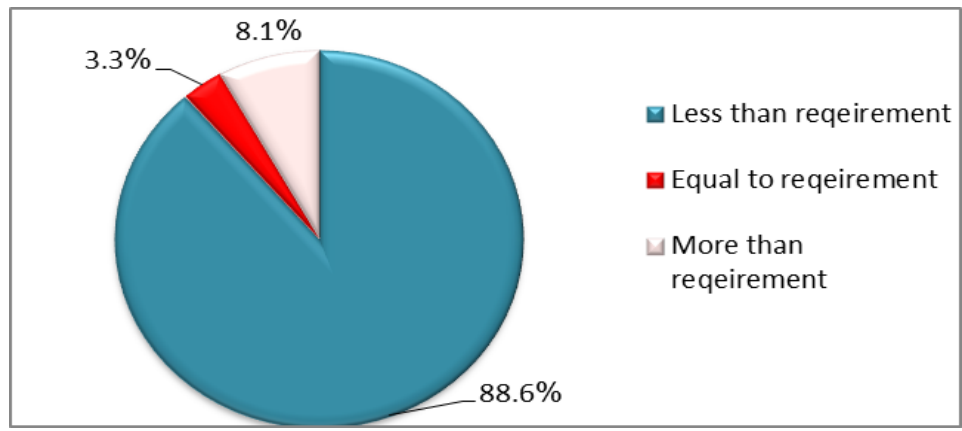

Fig-2: Distribution of Students According to Energy Intake

Shown, $(88.6 \%)$ of students consumed "less than the daily requirement", $(3.3 \%)$ were consumed "equal to requirement" and $(8.1 \%)$ were consumed "More than requirement". It was found that the daily energy intake of students (Kcal) was positively correlated with total and plain water consumed $(r=0.93$, $\mathrm{p}<0.001)$,) with $\mathrm{p}$ value $\mathrm{p}=0.000$.

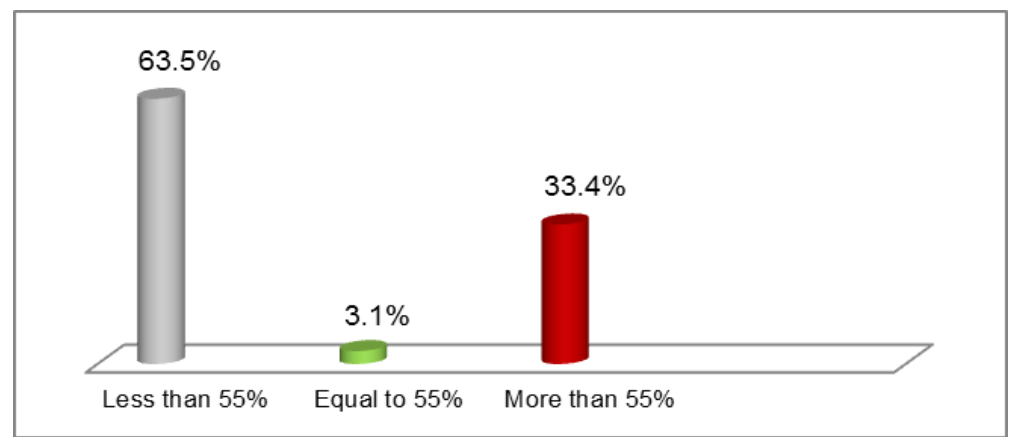

Fig-3: Assessment of daily carbohydrate intake of students

Shown, $(63.5 \%)$ of students consumed "less than $55 \%$ " of daily carbohydrate requirements, (33.4\%) of them consumed "more than (55\%") and (3.1\%) were consumed "equal to $55 \% "$. 


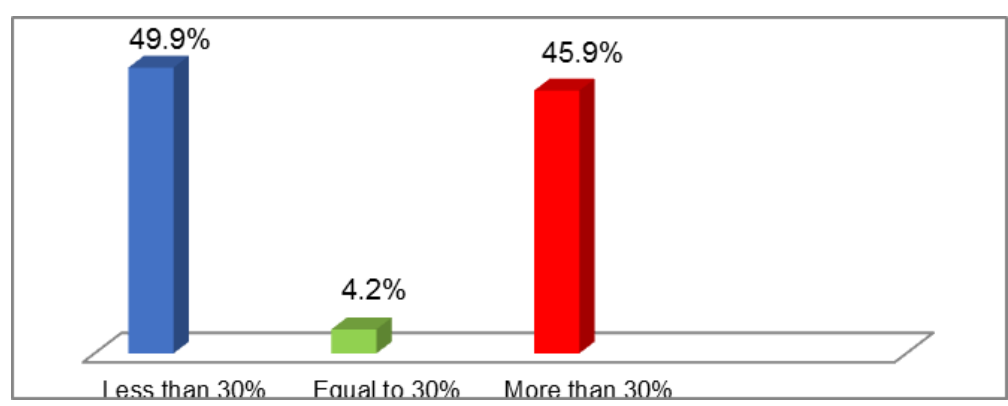

Fig-4: Assessment of daily fat intake of students

Shown, (49.9\%) of students consumed "less than $30 \%$ " of fat requirements, $(45.9 \%)$ were consumed "more than $30 \% "$ and $(4.2 \%)$ were consumed "equal to $30 \%$ of fat requirements".

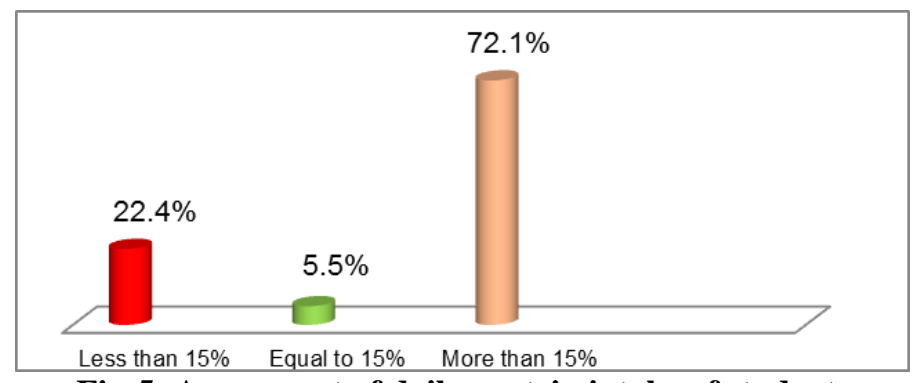

Fig-5: Assessment of daily protein intake of students

Shown, $(72.1 \%)$ of students were consumed "more than $15 \%$ " of protein requirements, $(22.4 \%)$ of students were consumed "less than $15 \%$ " and (5.5\%) were protein consumed "equal to $15 \%$ ".

\section{DisCUSSION}

This study was designed for evaluate the plain and total water intake (drinking fluids and water from foods) for medical college students in Benghazi University. A total number of (455) samples of medical college students where collected randomly, were divided to 224 samples male and 231 samples female aged from 19-30 years, were collected from five faculty including: medical, pharmacy, public health, dental and medical technique for all study years First, Second, Third and fourth. The results of this study revealed that the total water intake (water obtained from plain water, beverages and foods) among all participants, is $2600 \pm$ $1282 \mathrm{~mL}$, the plain water intake (pure water) of all students, $1627 \pm 1100 \mathrm{~mL}$, This is higher than the results that was presented by Drewnowski et al. in assessment of plain water in the younger adults group (20-50 years) which was $1294 \mathrm{~mL}$ for plain water and lower than total water $3560 \mathrm{ml} \mathrm{[36].} \mathrm{Definitely,} \mathrm{the}$ results of assessed total water value are also considered lower than the reported level in Kant and Graubard [37] study which was $3180 \mathrm{~mL}$ conducted from a single 24$\mathrm{hr}$ dietary recall in a national representative sample. The results of the current study suggest that gender is associated with total water intake and plain water intake, of which men had better adherence to the recommended intake levels were $68 \%$ of males and about $85.7 \%$ of females failed to meet the recommended values of total water. This indicates that men had slightly better compliance with the total water. Recommendation the male sample had a higher intake of pure water and of fluids obtained from pure water and beverages. Simillarly study by Alanazi 2018 [23], females' plain water intake was found to equal 1374 $\mathrm{mL}$, and males' plain water was $2183 \mathrm{~mL}$, while $82 \%$ of females and only $66 \%$ of males failed to adhere to the recommended IOM AIs (males: $3000 \mathrm{~mL}$; females: $2200 \mathrm{~mL}$ ). On the contrary, study conducted on thirteen countries in 2015 by Ferreira-Pêgo et al. investigated, men showed lower adherence to recommended levels compared to women, who showed more two-fold increase in the likelihood of adherence to water consumption recommendations [38]. Similarly, the results are discounted by Bellisle et al. who found that females have better compliance with the recommended [39].

Present results also show that Plain water were strongly and positively correlated with total water intake $(\mathrm{r}=0.92, \mathrm{p}<0.001)$, males' plain water intake $(2190 \pm 1363 \mathrm{~mL})$ is higher than females' plain water intake $(1384 \pm 992 \mathrm{~mL})$. Also the total water intake for male's $3300 \pm 1627 \mathrm{~mL}$ is higher than females total water intake $2360 \pm 1078 \mathrm{~mL}$. Likewise results of the assessed total water intake by gender showed that males' total water intake again is higher than females' intake. These findings suggested that in this study the male sample had a higher intake of pure water and of fluids obtained from pure water, beverages and foods [23]. Furthermore, IOM AIs for the total water intake, which is $3000 \mathrm{~mL}$ for males and $2700 \mathrm{~mL}$ for females, found to have more below recommended intakes. This indicates that men had slightly better compliance with 
the total water recommendation (IOM AIs). Moreover, our results are not consistent with Drewnowski et al. [36], who found that gender does not affect water intake.

The results showed that students aged between 23-26 years, n $321(70.5 \%)$ were the higher percentage between students. In our study the highest percentage of students in normal range of BMI especially in female. the majority of the participants male and female have normal body mass index especially female, were the results showed that $68.3 \%$ of students have BMI (normal ), $22.8 \%$ of them have a (over weight) BMI, $5 \%$ of students were BMI (obese), and $3.736 \%$ of them have BMI were (underweight). Similarly to a study conducted in 2018 by Sprake et al., the majority of the participants male and female have normal body mass index especially female [40]. However contrast with recent study by Teng et al., that showed overweight among the students was high at $23.9 \%$ [41], in comparison with our study the $66.1 \%$ in male and $70.6 \%$ in female of normal body mass index was the higher percentage. The rationale behind the difference of previous results about the MBI may be due to different life styles of university students in different situation and different dietary pattern [42].

Also comparison with study by Balaghi et al., fluids intake and beverage consumption pattern among university students, the results showed that general characteristics of students in both genders about $80 \%$ of students had normal BMI, their fluid intake was lower than recommended values [43]. Thus agreement with our work was the students consumed lower than the recommended intake for both gender.

The association between Physical activity, and water intake in male in this study the results showed that about $58.5 \%$ of students were sedentary life, $37.5 \%$ of them consumption less than $3 \mathrm{~L} /$ day, comparison with female $64.1 \%$ of students were sedentary life $54.1 \%$ of them consumption less than $2 \mathrm{~L} /$ day. The results also revealed that female and male nearly the same consumption about $193(42.4 \%)$ of female, 183 (40.2\%) male students, in contrast male students more consumption of Tea than female about 165 (36.3\%) of male students and $118(25.9 \%)$ of female students, and about $(42.6 \%)$ of male students and $(39.1 \%)$ of female students consumption about $0.25 \mathrm{ml}-1 \mathrm{~L}$ of coffee, while consumption for other beverages almost same about 80 $(17.6 \%)$ of male students and $75(16.5 \%)$ of female students. Thus more than the percentages that found with other study sweetened coffee or tea (18.4\%) and full cream milk $(9.6 \%)$. Besides plain water, most of the subjects consumed only $\leq 1$ cup of the beverage each time [37]. Our work results found that daily energy intake is positively correlated $(r=0.93, p=0.000)$ with both plain and total water intake, which is supported by Lee et al.'s research [44]. in similar An Assessment of Daily Plain Water Intake Level and Its Association with
Total Energy Intake Among College Students it was found that the daily energy intake (Kcal) was positively correlated $(\mathrm{r}=0.50)$ with total water intake $(\mathrm{mL})$ with $\mathrm{p}$ value $\mathrm{p}<0.001$ [23]. However, our results contradict the negative correlation discovered by Ann and McCaffrey who reported with every $1 \%$ increase of plain water in total water, the daily energy decreased by $8.5 \mathrm{Kcal}$ [45]. Alternatively, findings from Kant and Graubard stated that dietary energy intake is unrelated to plain water intake [37].

\section{CONCLUSION}

Our conclusion is that, the student's consumption of water less than the recommended $(3 \mathrm{~L} /$ day for male, $2.2 \mathrm{~L} /$ day for female). Encourage students for drinking enough water with exercise, such as walking, for students who are body mass index overweight or obese. Reducing the consumption of stimulants such as coffee and tea and, replacing them with drinks that are beneficial to the student. These findings suggest that more efforts must be done to encourage young students to consume more water as a measure for maintaining overall health and wellness.

\section{REFERENCES}

1. Wilson, J. A., Loveday, H. P., Hoffman, P. N., \& Pratt, R. J. (2007). Uniform: an evidence review of the microbiological significance of uniforms and uniform policy in the prevention and control of healthcare-associated infections. Report to the Department of Health (England). Journal of Hospital Infection, 66(4), 301-307.

2. RIVER, I. M. (2006). Evaluating land use change effects on river flow using USGS geospatial stream flow model in Mara River basin, Kenya. Center for Remote Sensing of Land Surfaces, 28, 30.

3. Blake, H. (2011). Healthy hydration in the workplace. Health Psychology Update, 20(2), 22.

4. Lunn, J., \& Foxen, R. (2008). How much water do we really need?. Nutrition bulletin, 33(4), 336342.

5. Charney, P. Water. (2008). Electrolytes, and acidbase balance. Krauses' Food and Nutrition Therapy. 2008. Ed, L Kathleen Mahan. S Escott stump. Whitmore SJ.12th ed, The United States of America: Rogers John, 145-148.

6. Benharroch, D., \& Ariad, S. (2012). Mild dehydration-possible association with bladder and colorectal cancers: a review. Journal of Food Processing and Technology, 3(2).

7. Charrière, N., Miles-Chan, J. L., Montani, J. P., \& Dulloo, A. G. (2015). Water-induced thermogenesis and fat oxidation: a reassessment. Nutrition \& diabetes, 5(12), e190e190.

8. Popkin, B. M., D'Anci, K. E., \& Rosenberg, I. H. (2010). Water, hydration, and health. Nutrition reviews, 68(8), 439-458. 
9. Deen, P. M., Verdijk, M. A., Knoers, N. V., Wieringa, B., Monnens, L. A., van Os, C. H., \& van Oost, B. A. (1994). Requirement of human renal water channel aquaporin-2 for vasopressindependent concentration of urine. Science, 264(5155), 92-95.

10. Greenleaf, J. E. (1994). Environmental issues that influence intake of replacement beverages. Washington, DC: National Academies.

11. Grandjean, A.C. (2005). Water requirements, impinging factors, and recommended intakes. Nutrients in drinking water, 25

12. Kleiner, S. M. (1999). Water: an essential but overlooked nutrient. Journal of the American Dietetic Association, 99(2), 200-206.

13. Radosavljević, V., Janković, S., Marinković, J., \& Djokić, M. (2003). Fluid intake and bladder cancer. A case control study. Neoplasma, 50(3), 234-238.

14. Sawka, M. N. (2005). Dietary Reference Intakes for Water, Potassium, Sodium, Chloride, and Sulfate. Chapter 4-Water. Army Research Inst of Environmental Medicine Natick MA.

15. Popkin, B. M., D'Anci, K. E., \& Rosenberg, I. H. (2010). Water, hydration, and health. Nutrition reviews, 68(8), 439-458.

16. Kleiner, S. M. (1999). Water: an essential but overlooked nutrient. Journal of the American Dietetic Association, 99(2), 200-206.

17. Latzka, W. A., \& Montain, S. J. (1999). Water and electrolyte requirements for exercise. Clinics in sports medicine, 18(3), 513-524.

18. Lotan, Y., Daudon, M., Bruyère, F., Talaska, G., Strippoli, G., Johnson, R. J., \& Tack, I. (2013). Impact of fluid intake in the prevention of urinary system diseases: a brief review. Current opinion in nephrology and hypertension, 22, S1-S10.

19. Deen, P. M., Verdijk, M. A., Knoers, N. V., Wieringa, B., Monnens, L. A., van Os, C. H., \& van Oost, B. A. (1994). Requirement of human renal water channel aquaporin-2 for vasopressindependent concentration of urine. Science, 264(5155), 92-95.

20. Guelinckx, I., Iglesia, I., Bottin, J. H., De MiguelEtayo, P., González-Gil, E. M., Salas-Salvadó, J., ... \& Moreno, L. A. (2015). Intake of water and beverages of children and adolescents in 13 countries. European journal of nutrition, 54(2), 6979.

21. Popkin, B. M., D'Anci, K. E., \& Rosenberg, I. H. (2010). Water, hydration, and health. Nutrition reviews, 68(8), 439-458.

22. Sawka, M. N., Burke, L. M., Eichner, E. R., Maughan, R. J., Montain, S. J., \& Stachenfeld, N. S. (2007). American College of Sports Medicine position stand. Exercise and fluid replacement. Medicine and science in sports and exercise, 39(2), 377-390.
23. Alanazi, M. (2018). An Assessment of Daily Plain Water Intake Level and Its Association with Total Energy Intake Among College Students.

24. Radosavljević, V., Janković, S., Marinković, J., \& Djokić, M. (2003). Fluid intake and bladder cancer. A case control study. Neoplasma, 50(3), 234-238.

25. Rodgers, A. (1999). Effect of cola consumption on urinary biochemical and physicochemical risk factors associated with calcium oxalate urolithiasis. Urological research, 27(1), 77-81.

26. Huang, Y. L., Song, W. O., Schemmel, R. A., \& Hoerr, S. M. (1994). What do college students eat? Food selection and meal pattern. Nutrition Research, 14(8), 1143-1153.

27. HUBERT, H. B., EAKER, E. D., GARRISON, R. J., \& Castelli, W. P. (1987). Life-style correlates of risk factor change in young adults: an eightyear study of coronary heart disease risk factors in the Framingham offspring. American Journal of Epidemiology, 125(5), 812-831.

28. Winkleby, M. A., \& Cubbin, C. (2004). Changing patterns in health behaviors and risk factors related to chronic diseases, 1990-2000. American Journal of Health Promotion, 19(1), 19-27.

29. Kvaavik, E., Andersen, L. F., \& Klepp, K. I. (2005). The stability of soft drinks intake from adolescence to adult age and the association between long-term consumption of soft drinks and lifestyle factors and body weight. Public health nutrition, 8(2), 149-157.

30. Balaghi, S., Faramarzi, E., Mahdavi, R., \& Ghaemmaghami, J. (2011). Fluids intake and beverage consumption pattern among university students. Health promotion perspectives, 1(1), 54.

31. Huang, Y. L., Song, W. O., Schemmel, R. A., \& Hoerr, S. M. (1994). What do college students eat? Food selection and meal pattern. Nutrition Research, 14(8), 1143-1153.

32. HUBERT, H. B., EAKER, E. D., GARRISON, R. J., \& Castelli, W. P. (1987). Life-style correlates of risk factor change in young adults: an eightyear study of coronary heart disease risk factors in the Framingham offspring. American Journal of Epidemiology, 125(5), 812-831.

33. Rodgers, A. (1999). Effect of cola consumption on urinary biochemical and physicochemical risk factors associated with calcium oxalate urolithiasis. Urological research, 27(1), 77-81.

34. Winkleby, M. A., \& Cubbin, C. (2004). Changing patterns in health behaviors and risk factors related to chronic diseases, 1990-2000. American Journal of Health Promotion, 19(1), 19-27.

35. Kvaavik, E., Andersen, L. F., \& Klepp, K. I. (2005). The stability of soft drinks intake from adolescence to adult age and the association between long-term consumption of soft drinks and lifestyle factors and body weight. Public health nutrition, 8(2), 149-157. 
36. Drewnowski, A., Rehm, C. D., \& Constant, F. (2013). Water and beverage consumption among adults in the United States: cross-sectional study using data from NHANES 2005-2010. BMC public health, 13(1), 1-9.

37. Kant, A. K., Graubard, B. I., \& Atchison, E. A. (2009). Intakes of plain water, moisture in foods and beverages, and total water in the adult US population-nutritional, meal pattern, and body weight correlates: National Health and Nutrition Examination Surveys 1999-2006. The American journal of clinical nutrition, 90(3), 655-663.

38. Ferreira-Pêgo, C., Guelinckx, I., Moreno, L. A., Kavouras, S. A., Gandy, J., Martinez, H., ... \& Salas-Salvado, J. (2015). Total fluid intake and its determinants: cross-sectional surveys among adults in 13 countries worldwide. European journal of nutrition, 54(2), 35-43.

39. Bellisle, F., Thornton, S. N., Hebel, P., Denizeau, M., \& Tahiri, M. (2010). A study of fluid intake from beverages in a sample of healthy French children, adolescents and adults. European journal of clinical nutrition, 64(4), 350-355.

40. Sprake, E. F., Russell, J. M., Cecil, J. E., Cooper, R. J., Grabowski, P., Pourshahidi, L. K., \& Barker, M. E. (2018). Dietary patterns of university students in the UK: a cross-sectional study. Nutrition journal, 17(1), 1-17.
41. Teng, N. I. M. F., Nordin, N. J., Suraya, A., \& Shah, M. (2019). Plain water and beverage consumption patterns among university students in Puncak Alam, Malaysia. Peer-reviewed Journal of the Nutrition Society of Malaysia, 25(2), 227.

42. Park, S., Blanck, H. M., Sherry, B., Brener, N., \& O'Toole, T. (2012). Factors associated with low water intake among US high school studentsNational Youth Physical Activity and Nutrition Study, 2010. Journal of the Academy of Nutrition and Dietetics, 112(9), 1421-1427.

43. Balaghi, S., Faramarzi, E., Mahdavi, R., Ghaemmaghami, J. (2011). Fluids Intake and Beverage Consumption Pattern among University Students. Health Promotion Perspectives, 1(1): 54 61.

44. Lee, K. W., Shin, D., \& Song, W. O. (2016). Total water intake from beverages andfoods is associated with energy intake and eating behaviors in Koreanadults. Nutrients, 8(10), 617. doi: 10.3390/nu8100617

45. An, R., \& McCaffrey, J. (2016). Plain water consumption in relation to energy intake anddiet quality among US adults, 2005-2012. Journal of human nutrition and dietetics, 29 (5), 624-632 https://doi.org/10.1111/jhn.12368

Cite This Article: Zahzahan A. Alsaeti et al (2021). An Assessment of Daily Plain Water, Fluid Intake Levels and Its Association with Total Energy Intake among Medical Students in Benghazi University in Libya. EAS J Nutr Food Sci, 3(2), 50-61. 